\title{
Phylogenetic relationships within Oweniidae Rioja (Polychaeta, Annelida)
}

Gustavo Sene-Silva $^{1}$

\begin{abstract}
The Oweniidae consist of five genera of tubiculous polychaetes occurring in all oceans from tropical to polar areas: Owenia Delle Chiaje, 1842, Myriochele Malmgren, 1867, Galathowenia Kirkegaard, 1959, Myriowenia Hartman, 1960 and Myrioglobula Hartman, 1967. The group is regarded as monophyletic based on the presence of dense fields of bidentate neuropodial hooks. Fourteen species were submitted to a cladistic analysis in PAUP 3.1.1 with the usage of 19 morphological characters. The taxonomic status of the ingroup taxa could be evaluated and it has been found that: (1) Owenia, Myriowenia and Myrioglobula are monophyletic, and (2) Myriochele, and Galathowenia are both paraphyletic taxa.

KEY WORDS. Polychaeta, Oweniidae, phylogeny, systematics
\end{abstract}

The Oweniidae Rioja, 1917 are polychaetes with large bathymetric range. They are usually collected from intertidal zones to shallow waters and are rare in great depths, being present in all oceans from tropical to polar areas. The Oweniidae currently consist of five genera: Owenia Delle Chiaje, 1842, Myriochele Malmgren, 1867, Galathowenia Kirkegaard, 1959, Myriowenia Hartman, 1960, and Myrioglobula Hartman, 1967. They all inhabit tubes.

In terms of taxonomical diagnosis, these genera seem to be relatively well defined, except for Myriochele and Galathowenia. Some oweniid polychaetes, as for example Myriochele fragilis Nilsen \& Holthe, 1985 and M. longicollaris Hartmann-Schröder \& Rosenfeldt, 1989, have been described and ranked in the cited genus. However, the description of their head region (a collar-like cylindrical structure anterior to the mouth) does not fit with the original diagnosis of a globular head for Myriochele (MALMGREN 1867). Apparently, the inclusion of these species in Myriochele was based purely on the absence of head appendages and on a thoracic region of three uniramous segments (Fig. 1A), even though Galathowenia was already described by KIRKEGAARD (1959).

Moreover, Myriochele species might have been equivocally cited in some biogeographical studies published in past reports, due to possible cases of bad fixation of collected material (BERKELEY 1949). This author suggests that some specimens with collar-like prostomial membranes could have their anterior ends contracted after the application of fixative substances and gained a globular appearance, similar to the pattern found in Myriochele heeri Malmgren, 1867. This does not directly affect, however, an attempt to understand the distribution of the internal taxa within the Oweniidae according to an hypothesis of evolution of their characters under a phylogenetic perspective.

1) Departamento de Zoologia, Universidade Federal do Paraná. Caixa Postal 19020, 81531-980 Curitiba, Paraná, Brasil. E-mail: gssilva@ bio.ufpr.br

Former address: Zoomorphologie und Systematik (Abt. 2), Fakultät für Biologie, Universität Bielefeld, Germany. 
FITZHUGH $(1987,1989)$ and PLEIJEL (1991) are examples of attempts on the internal phylogeny of some polychaete families. Other works have treated the Polychaeta in general (WESTHEIDE et al. 1999), or considered their general evolutionary transformations (WESTHEIDE 1997), or even the relationship-levels of their internal taxa with morphological characters (ROUSE \& FAUCHALD 1997; ROUSE 1999) and also with molecular data (MCHUGH 1997; KoJIMA 1998). Particularly in the Oweniidae, Nilsen \& Holthe (1985) and Meyer \& BARTOlOMAeus (1996) proposed their ideas on the ground plan of this taxon based on hypothesised evolutionary steps of the transformation of the neurochaetae (morphology and position along the body). Although these works did not involve other characters, which would imply directly in the oweniid internal phylogeny, they are important contributions due to information on species biogeography, general descriptions of features, detailed data on the morphology and morphogenesis of characters and mainly because of the preliminary insights concerning possible evolutionary transformations within genera.

This paper represents a cladistic analysis to unravel the phylogeny of the Oweniidae. Inferences on the transformation of each of the characters were possible and, consequently, a ground plan of the group is hypothesised in accordance to the most primitive features found in the single most-parsimonious tree obtained. Furthermore, the resulting final topology could demonstrate the most suitable sister-group relationship among each of the species studied, permitting an evaluation of the validity of their taxonomic ranking under Hennigian principles of monophyly (HENNIG 1966; WILEY 1981; AMORIM 1997).

\section{MATERIAL AND METHODS}

\section{Taxa}

The phylogenetic relationship of fourteen species of Oweniidae was determined using phylogenetic systematics (HENNIG 1966). The characters were obtained from the primary literature or directly through the study of specimens. The species considered are: Owenia fusiformis Delle Chiaje, 1842, Myriochele heeri Malmgren, 1867, Myriochele danielsseni Hansen, 1879, Galathowenia oculata (Zachs, 1923), Myriochele pygidialis Hartman, 1960, Myriowenia californiensis Hartman, 1960, Myriowenia gosnoldi Hartman, 1965, Myrioglobula antarctica Hartman, 1967, Galathowenia scotiae (Hartman, 1978), Myriochele fragilis Nilsen \& Holthe, 1985, Myrioglobula japonica Imajima \& Morita, 1987, Myriochele logicollaris Hartmann-Schröder \& Rosenfeldt, 1989, Myriochele joinvillensis Hartmann-Schröder \& Rosenfeldt 1989, and Owenia gomsoni Koh \& Bhaud, 2001.

\section{Choice of outgroup taxa}

A well-stablished sister-group for the Oweniidae is not in consensus, yet, since they are related differently in each publication to a distinct polychaete taxon (Nilsen \& Holthe 1985; Rouse \& Fauchald 1997; Bartolomaeus 1997; RouSE 1999). Spionidae Grube, 1850 and Sabellidae Malmgren, 1867 were chosen as outgroups only in order to root the cladogram, once they represent real entities which are, at least, closely related to the Oweniidae within the phylogeny of 
polychaetes. Those groups, as well as the Oweniidae themselves, have been treated and recognized in the recent literature (ROUSE \& FAUCHALD 1997; BARTOLOMAEUS 1997; HAUSEN \& BARTOLOMAeUS 1998; SCHWEIGKOFLER et al. 1998; ROUSE 1999) as closely related groups, which are capable of tube secretion around the body, and are deposit-or filter-feeding worms. Moreover, they all present at least a pair of peristomial grooved palps, which defines the more inclusive clade Canalipalpata (ROUSE \& FAUCHALD 1997).

\section{Parsimony analysis}

The computer program PAUP 3.1.1 (SWOFFORD 1993) was used to analyse the data matrix of 16 taxa and 19 characters (Tab. I). These were all treated as unweighted and unordered. No autapomorphic characters were primarily applied. The trees were rooted using the method of outgroup comparison according to standard procedures for cladistic analysis in order to polarise the transformations (WATrous \& WHEeler 1981; Wiley 1981; AMORIM 1997). The searches were performed using the command "Branch and Bound Search" and zero-length branches were collapsed. The option "Root tree at internal node with basal polytomy" was applied. The character transformations of the single most-parsimonious tree were studied using MacClade 3.05 (MADDISON \& MADDISON 1992).

Table I. Data matrix with 16 taxa and 19 unweighted and unordered characters. Characters coded as numbers from " 0 " to " 3 "; missing data coded as "?".

\begin{tabular}{|c|c|c|c|c|c|c|c|c|c|c|c|c|c|c|c|c|c|c|c|}
\hline \multirow{2}{*}{ Taxa } & \multicolumn{19}{|c|}{ Characters } \\
\hline & 1 & 2 & 3 & 4 & 5 & 6 & 7 & 8 & 9 & 10 & 11 & 12 & 13 & 14 & 15 & 16 & 17 & 18 & 19 \\
\hline Spionidae & 0 & 0 & 1 & 0 & 0 & 0 & 0 & 0 & 0 & 0 & 0 & 0 & 0 & 0 & 0 & 0 & 0 & 0 & 1 \\
\hline Sabellidae & 0 & 0 & 1 & 0 & 0 & 0 & 0 & 0 & 0 & 0 & 0 & 0 & 0 & 0 & 1 & 0 & 0 & 0 & 0 \\
\hline Myriowenia gosnoldi & 0 & 1 & 1 & 0 & 0 & 0 & 1 & 0 & 0 & 0 & 0 & 1 & 0 & 1 & 3 & 0 & 1 & 0 & 1 \\
\hline Myriowenia californiensis & 0 & 1 & 1 & 0 & 0 & 1 & 1 & 0 & 0 & 0 & 0 & 1 & 0 & 1 & 3 & 0 & 1 & 0 & 0 \\
\hline Myriochele heeri & 1 & 0 & 0 & 0 & 0 & 1 & 0 & 0 & 0 & 0 & 0 & 1 & 0 & 1 & 3 & 0 & 0 & 1 & 0 \\
\hline Myrioglobula antarctica & 1 & 0 & 0 & 0 & 0 & 1 & 0 & 0 & 0 & 0 & 0 & 1 & 0 & 1 & 1 & 2 & 0 & 1 & 0 \\
\hline Myrioglobula japonica & 1 & 0 & 0 & 0 & 0 & 1 & 0 & 0 & 0 & 0 & 0 & 1 & 0 & 1 & 1 & 0 & 0 & 1 & 0 \\
\hline Myriochele joinvillensis & 0 & 0 & 0 & 1 & 0 & 0 & 0 & 0 & 0 & 0 & 0 & 1 & 0 & 1 & 2 & 0 & 0 & 0 & 0 \\
\hline Myriochele fragilis & 0 & 0 & 0 & 1 & 0 & 0 & 0 & 1 & 0 & 0 & 0 & 1 & 0 & 1 & 3 & 0 & 0 & 0 & 0 \\
\hline Myriochele pygidialis & 0 & 0 & 0 & 1 & 0 & 0 & 0 & 1 & 0 & 0 & 0 & 1 & 0 & 1 & 3 & 1 & 0 & 0 & 0 \\
\hline Myriochele longicollaris & 0 & 0 & 0 & 1 & 0 & 0 & 0 & 1 & 1 & 0 & 0 & 1 & 0 & 1 & 3 & 1 & 0 & 0 & ? \\
\hline Galathowenia scotiae & 0 & 0 & 0 & 1 & 0 & 0 & 0 & 1 & 1 & 0 & 0 & 1 & 0 & 1 & 3 & 1 & 0 & 0 & 0 \\
\hline Galathowenia oculata & 0 & 0 & 0 & 1 & 1 & 0 & 0 & 1 & 1 & 0 & 0 & 1 & 0 & 1 & 3 & 1 & 0 & 0 & 0 \\
\hline Myriochele danielsseni & 0 & 0 & 0 & 1 & 1 & 0 & 0 & 1 & 0 & 1 & 1 & 1 & 1 & 1 & 3 & 2 & 0 & 0 & 0 \\
\hline Owenia fusiformis & 0 & 0 & 0 & 2 & 1 & 0 & 0 & 0 & 1 & 1 & 1 & 1 & 1 & 1 & 3 & 2 & 0 & 0 & 0 \\
\hline Owenia gomsoni & 0 & 0 & 0 & 2 & 1 & 0 & 0 & 0 & 1 & 1 & 1 & 1 & 1 & 1 & 3 & 2 & 0 & 0 & 0 \\
\hline
\end{tabular}

\section{Characters}

1) Slit-like bucal opening: (0) absent; (1) present. The mouth of Myriochele heeri, Myrioglobula antarctica and $M$. japonica have an unconventional form, being rather elongated longitudinally, which gives them the appearance of an anterior slit (Fig. 1A). 
2) Labial lobes: (0) absent; (1) present. HARTMAN (1960, 1967) described for Myriowenia species a pair of proximal rounded expansions localized in the same region where the peristomial palps attach to the anterior end. No other species of Oweniidae or outgroups have such character.

3) Peristomial grooved palps: (0) absent; (1) present. The Canalipalpata involves the polychaete groups Spionida, Terebellida and Sabellida (ROUSE \& FAUCHALD 1997), which are annelids with ciliated longitudinal grooves along their peristomial palps. The homology between these palps is very well substantiated neurologically according to a series of studies performed by ORRHAGE (1964, 1978, 1980). They appear also in the Oweniidae (included in Sabellida), though only in Myriowenia species.

4) Prolonged peristomial lips: (0) absent; (1) present; (2) present and lobed. A cylindrical membranous structure extended anteriorly from the mouth and ciliated in its inner surface with a pronounced longitudinal ventral slit represents elongated lips found particularly in some oweniid taxa (Myriochele joinvillensis, $M$. fragilis, $M$. longicollaris, $M$. danielsseni, Galathowenia scotiae and G. oculata). These lips are modified as dichotomously lobed structures in Owenia species (BERKELEY 1949).

5) Peristomial ventro-lateral eyespots: (0) absent; (1) present. Eyespots have been reported for many polychaete groups (FAUCHALD \& ROUSE 1997), generally found in the dorsal surface of prostomium or peristomium. Ventro-lateral localized eyes on the collar (oweniid peristomial region) are, however, observed only in some of the species studied, namely G. oculata, $M$. danielsseni, $O$. fusiformis, and O. gomsoni (see, for example, in WILSON 1932; BLAKE \& DEAN 1973; IMAJIMA \& MORITA 1987).

6) Globular head region: (0) absent; (1) present. The cephalic region of Myriowenia californiensis, Myriochele heeri (Fig. 1A), Myrioglobula antarctica and M. japonica have a notably globular shape. In the first mentioned taxon, however, a cylindrical area on the peristomium precedes the first setiger; in the other cited species the globular region is directly adjacent to the first setiger.

7) Length of thoracic segments: (0) wider than long; (1) longer than wide. Myriowenia species have their thoracic segments much longer than wide and approximately as long as, at least, the median ones.

8) Constriction between first and second setiger: (0) absent; (1) present. Some oweniid species, namely Galathowenia oculata, G. scotiae, Myriochele pygidialis, $M$. danielsseni, $M$. fragilis and $M$. longicollaris, present a transverse constriction that demarks a circular area between first and second setigers (for examples see IMAJIMA \& MORITA 1987; FIEGE et al. 2000). PARAPAR (2001) has recently worked on a revision of some oweniid species with special concern for this character. He states that this constriction on the thoracic region is an intermediate phase between a normal state of the animal and a breakage process of the anterior end, which might involve asexual reproduction. His main observation demonstrated that Myriochele scotiae Hartman, 1978 is a senior synonym of Galathowenia wilsoni Blake, 1984, being the former species a broken version of the latter. He emended $M$. scotiae 's description and suggested a new combination, Galathowenia scotiae (Hartman, 1978). 

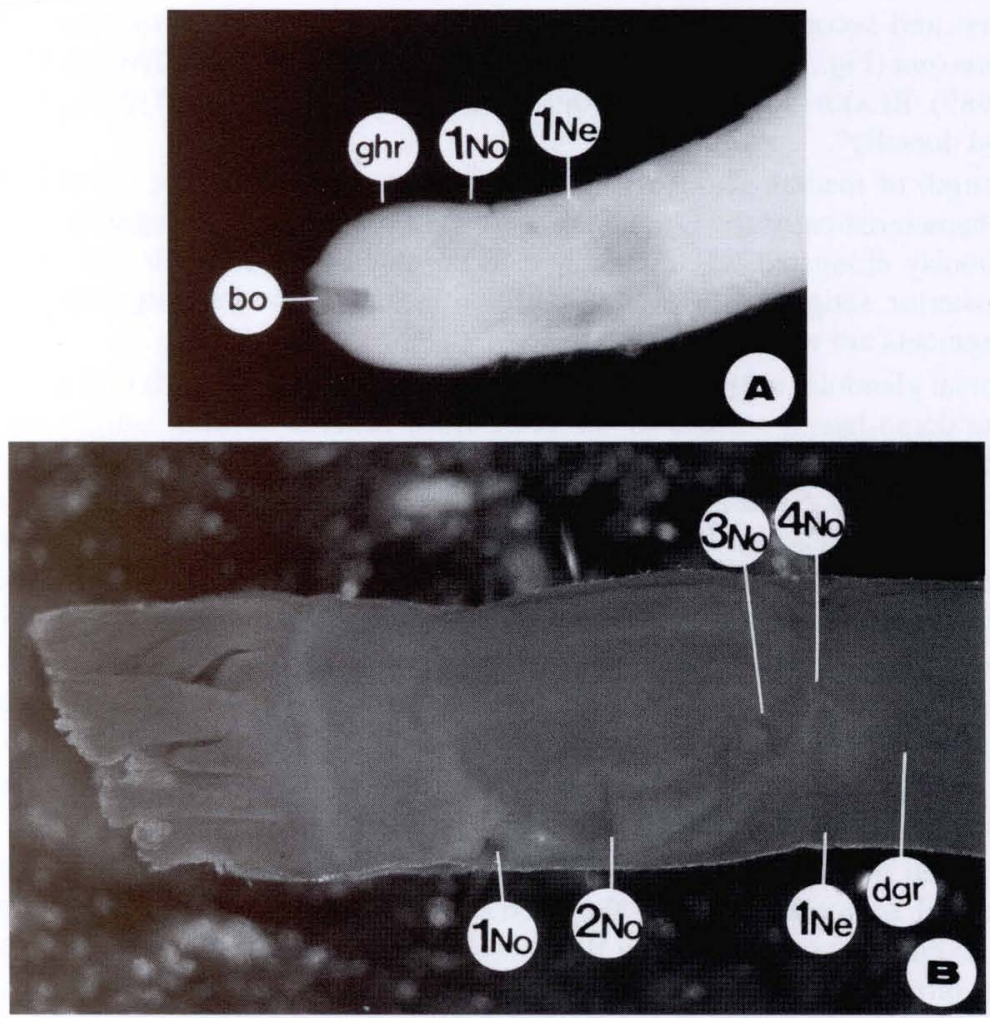

Fig. 1. (A) Ventral view of anterior end of Myriochele heeri. (B) Dorso-lateral view of anterior end of Owenia fusiformis. (bo) Bucal opening, (dgr) dorsal glandular ridge, (ghr) globular head region, (Ne) neuropodium, (No) notopodium, numbers 1-4 correspond to setiger number.

9) Y-like midventral line: (0) absent; (1) present. Five of the oweniid species studied (M. longicollaris, G. scotiae, G. oculata, $O$. fusiformis and $O$. gomsoni) present a pair of ventro-lateral lines (usually brighter than the rest of the body), which originate posteriorly to the collar margin and close to each of the eyespots regions. These lines converge and meet each other between the first and the second setigers on their ventral side.

10) Length of third segment: (0) isometric to first segment; (1) shorter than first segment. The so-called thoracic segments in Oweniidae are recognized as being much shorter than the anterior most abdominal ones. The third thoracic setiger is relatively even shorter than the first and second ones in Myriochele danielsseni, O. fusiformis (Fig. 1B) and $O$. gomsoni.

11) Position of third notopodia: (0) dorso-lateral; (1) dorsal. The notopodia fascicles of the third segment are closer to each other when compared to the ones of the 
first and second segments in Myriochele danielsseni, $O$. fusiformis and $O$. gomsoni (Fig. 1B, figures in NILSEN \& HOLTHE 1985 and IMAJIMA \& MORITA 1987). BLAKE (2000) refers to this same character as "setiger 3 short, constricted dorsally".

12) Length of median segments: (0) isometric to other segments; (1) elongated. Characteristically, the Oweniidae seem to have their median segments conspicuously elongated when compared to the three more anterior and the more posterior setigers. The same condition is not found in outgroups, where segments are wider than long.

13) Dorsal glandular ridges: (0) absent; (1) present. These are glands that appear on the dorso-lateral surface of the body from forth to seventh setiger and are disposed as two curved patches on each side of the segment. They begin just adjacent to its correspondent notopodium, bend to setiger's lateral region until its middle section and then merge again to the dorsal surface reaching the notopodium of the next setiger. This feature appears in Myriochele danielsseni and in Owenia species (Fig. 1B, illustrations in NILSEN \& HOLTHE 1985 and IMAJIMA \& MORITA 1987).

14) Neurochaetal hooks in dense fields: (0) absent; (1) present. Densely located hooks on the neuropodia are found on each oweniid studied so far (Fig. 1B). FAUCHALD \& ROUSE (1997) regarded this character as a significant synapomorphy of Oweniidae.

15) Position of first pair of neuropodia: (0) from the first segment; (1) from the second segment; (2) from the third segment; (3) from the forth segment. According to a revision from BLAKE (1996), the Spionidae present all parapodia birramous. In sabellids, the first thoracic segment bears only notopodia, and neuropodia (biramous parapodia) appear on second segment onwards (FITZHUGH 1989; FAUCHALD \& RoUSE 1997). Within the ingroup taxa, neuropodia appearing from the second segment is found in Myrioglobula species, whereas Myriochele joinvillensis present the first pair of neuropodia on the third segment. All other oweniid species considered in this study have their first pair of neuropodia on the forth segment (Figs 1A, B).

16) Shape of bifurcated neurochaetal hooks: (0) teeth longitudinally bifurcated; (1) teeth in an oblique plane to the manubrium; (2) teeth side-by-side in plane approximately in right angle to the manubrium. Neurochaetal hooks have been reported for many polychaete groups (e.g. oweniids, spionids, capitellids, arenicolids) and their homology have been demonstrated in recent papers (BARTOlOMAeUs 1995, 1997; MEYer \& BARTOlOMAeUs 1996; BARTOLOMA-

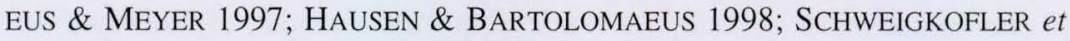
al. 1998). Particularly within the oweniids, these structures seem to present somewhat gradual modifications in respect to the compared position between both teeth: a longitudinal disposition very similar to that found in other polychaetes (like in spionids), then an intermediate condition with two teeth oblique to the other compared to the main manubrium axis and eventually a nearly parallel one found in a few taxa. 
17) Neurochaetal capitium: (0) appearing above rostrum; (1) vestigial. Unlike other oweniids, Myriowenia species present hooks with vestigial capitia, whereas the other species studied are clearly bifurcated.

18) Flattened posterior segments: (0) absent; (1) present. Dorso-ventrally flattened posterior most segments were cited for Myrioglobula species and Myriochele heeri (IMAJIMA \& MORITA 1987). A cylindrical condition seems to be encountered in other oweniid taxa.

19) Tentacle-like pygidial cirri: (0) absent; (1) present. A pair of long terminal cirri located dorsally to the anal opening has been described for Myriowenia gosnoldi. This structure is not found in any other oweniid species. The pygidial region of Myriochele longicollaris is unknown (HARTMANN-SCHRÖDER \& ROSENFELDT 1989; PARAPAR 2001).

\section{RESULTS AND DISCUSSION}

\section{Cladistic analysis}

The "Branch and Bound Search" command obtained one minimum-length tree for the data matrix (Tab. I). This single tree has a length of 29 steps with a consistency index (CI) of 0.793 , retention index (RI) of 0.878 and rescaled consistency index $(\mathrm{RC})$ of 0.696 . The tree is represented in figure 2 .

\section{Monophyly of the Oweniidae}

Three characters supported the monophyletic status of the Oweniidae in this study. Although found in a distinct segment in some species, neuropodial hooks from the fourth segment is observed basally in the phylogeny of these polychaetes. Of the outgroups used, setae appear from the first (Spionidae) or from the second (Sabellidae) segment, so the presence of neuropodial hooks in more anterior segments in some oweniid species should be interpreted as reversals. This characterizes a monophyletic group, Myrioglobula, with neurochaetae appearing from the second setiger. Another state represents a diagnostic feature of Myriochele joinvillensis, with neurochaetae appearing from the third setiger.

The two other characters that make the Oweniidae a monophyletic clade are present in all species included in the present study: (1) the neuropodial patches with fields of densely concentrated bifurcated hooks and (2) the conspicuously elongated median segments in the abdominal region.

\section{Myriowenia monophyletic status}

The monophyly of Myriowenia is supported by three synapomorphies. The first is the vestigial apical tooth on neuropodial hooks, as the tree obtained showed that it is more likely that the longitudinally bifurcated hooks with well-developed teeth were already present in the stem species of the Oweniidae. The second feature is the elongated state of the three thoracic segments, while other oweniids have retained the short ancestral condition. Another particular character for this taxon is the pair of labial lobes located close to the insertion of the basis of each of the peristomial tentacles and the head. 


\section{Myrioglobula relationships}

Regarding the cladogram in figure 2, one can see that Myriochele heeri, Myrioglobula antarctica and $M$. japonica form together another monophyletic group within the Oweniidae. A slit-like mouth, a globular head (Fig. 1A) and dorso-ventrally flattened posterior segments (IMAJIMA \& MORITA 1987) are the synapomorphies of this taxon. Also, the monophyly of Myrioglobula is characterized by the presence of neurochaetae from the second segment onwards (see above).

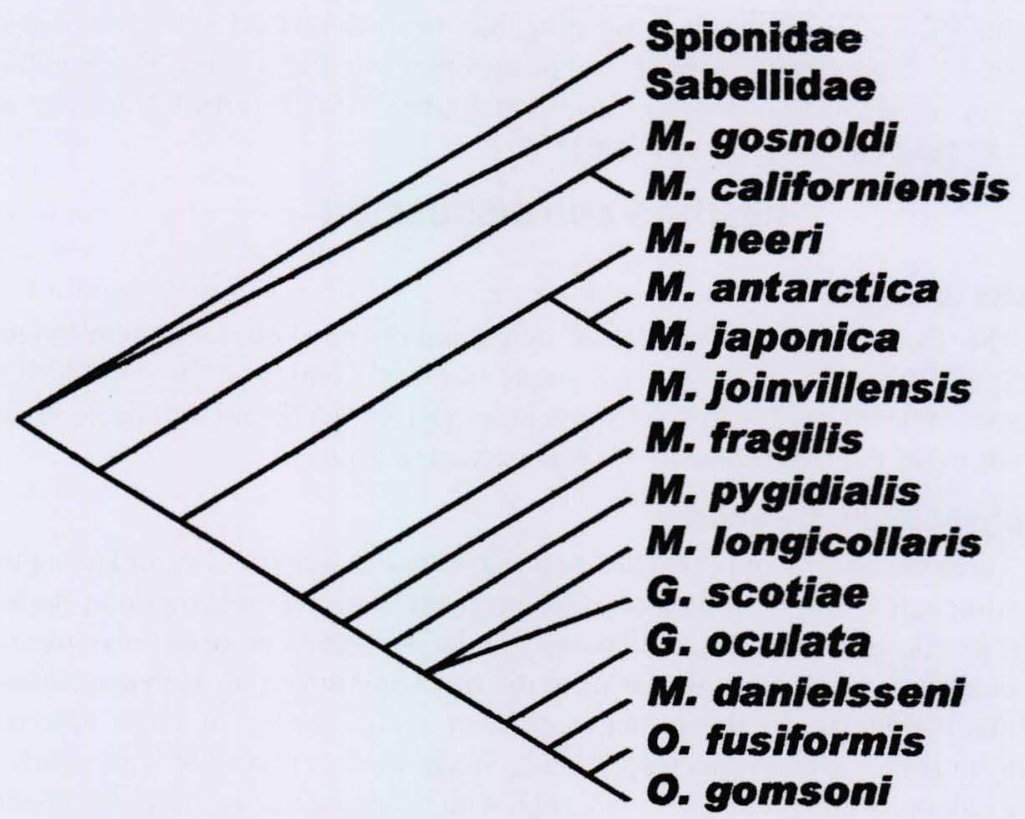

Fig. 2. The single-most parsimonious tree obtained from data matrix (Tab. I) with length of 29 steps and $\mathrm{Cl} 0.793$.

\section{Owenia monophyly and its outgroups}

The clade that extends from Myriochele joinvillensis to Owenia gomsoni (Fig. 2) is defined by the presence of a cylindrical collar-like structure surrounding the mouth. This latter structure represents the buccal lips, which extends anteriorly from the mouth with a longitudinal ventral slit and a densely ciliated inner-surface. The monophyletic group comprising from $M$. fragilis to $O$. gomsoni has the transversal fold between first and second segments as synapomorphy. Since this character is not found in Owenia, it was interpreted as a reversal for this genus.

The 'side-by-side' type of neuropodial hooks with teeth in oblique position to the manubrium characterizes the next step in the cladogram. Within this group, no characters could define a more precise position for Myriochele longicollaris and Galathowenia scotiae, but both share the Y-like line on the ventral side of the body 
with G. oculata, Owenia fusiformis and $O$. gomsoni (reversal for $M$. danielsseni). G. oculata, $M$. danielsseni, Owenia fusiformis and $O$. gomsoni are disposed in a single clade characterized by a pair of peristomial ventro-lateral eyespots.

Owenia was found to be sister-group to Myriochele danielsseni. Four characters form the set of synapomorphies at this level, one of them being the neuropodial hooks with both teeth approximately at the same plane at right angles to the shaft, homoplastic to a similar condition found in Myrioglobula antarctica. In Owenia and Myriochele danielsseni, the third thoracic segment is reduced when compared to the other first one, and the distance between its notopodia is shorter than what occurs on the first segment. Additionally, dorsal glandular ridges along the elongated abdominal segments are present only in this clade (Fig. 2).

The genus Owenia was obtained as a monophyletic group. The anterior cylindrical structure (lips) found in more basal groups (see above) is modified in this taxon as lobes divided dichotomously, forming a crown-like structure. BERKELEY (1949) proposed such homology in the way that both organs are collar-like in appearance and possess ventral median glands, which secrete the mucous material used in their tubes. Moreover, their relative morphological position - a peristomial ring immediately anterior to the first setiger - and the presence of the ventro-lateral eyespots near the basis of the peristomium of some species reinforces Berkeley's evidences.

As a consequence of the congruence of the characters used, the present analysis showed another important result: the paraphyly of Myriochele and Galathowenia. The species of both genera form together a grade "inserted between" Myriowenia and Owenia, appearing the Myrioglobula species localized as a sistergroup of Malmgren's Myriochele heeri, and Myriochele danielsseni as closely related to Owenia. This fact suggests that the taxonomy of the family might suffer substantial alterations at the generic level.

\section{CONCLUSIONS}

This cladistic analysis of some species of Oweniidae proposes the monophyletic status of the family, even considering that not all described species of this taxon were included. Such species might very likely fit well within any of the different levels of the present phylogeny (Fig. 2). Hence, not only must their general features agree with any of the nodes on which they could be most probably related, but also with the ground plan encountered for the group.

MEYER \& BARTOLOMAEUS (1996) proposed a different interpretation concerning the number of thoracic setigers in the ground plan of Oweniidae. In that paper, the condition found in Myrioglobula antarctica for the neurochaetal patches (from the second segment onwards) should be interpreted as more plausible to be found in the stem species of the Oweniidae, because it is also present in terebellidan and sabellidan groups. It is possible that the neuropodial tori from the second segment onwards are the plesiomorphic state of this character for Terebellida and Sabellida. However, this has not been demonstrated in the present cladistic tests for the Oweniidae, where the congruence among the used characters showed that the most likely condition is the neuropodial tori present from the fourth setiger onwards. 
The internal sister-group relationship among the oweniid species was also obtained (Fig. 2). The results showed that only three of the five genera are monophyletic: Myriowenia, Myrioglobula and Owenia. The other two genera (Myriochele and Galathowenia) are paraphyletic. Myriochele's paraphyletism encountered in this study agrees with the anterior insight of NILSEN \& HOLTHE (1985).

\begin{abstract}
ACKNOWLEDGMENTS. The author wishes to specially thank Prof. Dr. Dalton S. Amorim and Prof. Dr. Martin L. Christoffersen for their substantial participation on the theoretical background in this project and with the bibliography. I am indebted to Prof. Dr. Thomas Bartolomaeus, Dr. Frederik Pleijel and an anonymous reviser for their brilliant comments on the manuscript. Prof. Bartolomaeus is also gratefully acknowledged for the kind allowance for the usage of his technical resources. Dr. Harald Hausen and Prof. Dr. Antônio Carlos Marques gave very helpful technical support with the computer programs. This study was supported by FAPESP (Proc. 97/06496-3) and CAPES.
\end{abstract}

\title{
REFERENCES
}

Amorim, D.S. 1997. Elementos básicos de sistemática filogenética. Ribeirão Preto, SP (Brazil), Sociedade Brasileira de Entomologia, Holos Editora, XVIII+276p.

Bartolomaeus, T. 1995. Structure and formation of the uncini in Pectinaria auricoma (Terebellida) and Spirorbis spirorbis (Sabellida): implications for annelid phylogeny and the position of the Pogonophora. Zoomorphology, Berlin, 115 (3): 161-177.

.1997. Chaetogenesis in polychaetous Annelida: significance for annelid systematics and the position of the Pogonophora. Zoology, Jena, 100: 348-364.

Bartolomaeus, T. \& K. Meyer. 1997. Morphogenesis and phylogenetic significance of hooked setae in Arenicolidae (Polychaeta, Annelida). Invertebr. Biol., Lawrence, 116 (3): 227-242.

BERKELEY, E. 1949. Morphological characters of Myriochele heeri Malmgren, 1867. Nature, London, 4162: 239

Blake, J.A. 1996. Family Spionidae Grube, 1850, p. 81-223. In: J.A.BlaKe; B. Hilbig \& P.H. ScotT (Eds). Taxonomic atlas of the Santa Maria Basin and western Santa Barbara Channel. The Annelida, Part 3, Polychaeta: Orbiniidae to Cossuridae. Santa Barbara, Santa Barbara Museum of Natural History, Vol. 6, 348p.

. 2000. Family Oweniidae Rioja, 1917, p. 97-127. In: J.A. BlaKe; B. Hilbig \& P.V. ScotT (Eds). Taxonomic Atlas of the benthic fauna of the Santa Maria Basin and the Western Santa Barbara Channel. The Annelida Part 4: Polychaeta: Flabelligeridae to Sternaspidae. Santa Barbara, Santa Barbara Museum of Natural History, Vol. 7, 348p.

BLAKE, J.A. \& D. DEAN. 1973. Polychaetous annelids collected by the R/V HERO from Baffin Island, Davis Strait, and West Greenland in 1968. Bull. South Calif. Acad. Sci., Los Angeles, 72 (1): 31-39.

Fauchald, K. \& G. Rouse. 1997. Polychete systematics: past and present. Zool. Scr., Oxon, 26 (2): 71-138.

FIEGE, D.; I. KRÖNCKE \& R. BARnich. 2000. High abundance of Myriochele fragilis Nilsen \& Holthe, 1985 (Polychaeta: Oweniidae) in the deep sea of the Eastern Mediterranean. Hydrobiologia, Dordrecht, 426: 97-103.

FITZHUGH, K. 1987. Phylogenetic relationships within the Nereididae (Polychaeta): implications at the subfamily level. Bull. Biol. Soc. Wash. 7: 174-183.

-1989. A systematic revision of the Sabellidae-Caobangiidae-Sabellongidae complex (Annelida: Polychaeta). Bull. Amer. Mus. Nat. Hist., New York, 192: 1-104.

HARTMAN, O. 1960. Systematic account of some marine invertebrate animals from the deep basins off southern California. Allan Hancock Pacific Expeditions, Los Angeles, 2 (22): 69-216.

Revta bras. Zool. 19 (4): 999 - 1010, 2002 
1967. Polychaetous annelids collected by the USNS Eltanin and Staten Island cruises, chiefly from Antartic seas. Allan Hancock Monographs in Marine Biology, Los Angeles, 2: 1-387.

Hartmann-Schröder, G. \& P. Rosenfeldt. 1989. Die Polychaeten der "Polarsten"-Reise ANT III/2 in die Antarktis 1984 - Teil 2, Cirratulidae bis Serpulidae. Mitt. Hambg. Zool. Mus. Inst., Hamburg, 86: 65-106.

Hausen, H. \& T. Bartolomaeus. 1998. Setal structure and chaetogenesis in Scolelepis squamata and Malacoceros fuliginosus (Spionidae, Annelida). Acta Zool., Stockholm, 79 (3): 149-161.

Hennig, W. 1966. Phylogenetic systematics. Urbana, Univ. Illinois Press, 263p.

Imajima, M. \& Y. Morita. 1987. Oweniidae (Annelida, Polychaeta) from Japan. Bull. Natl. Sci. Mus., Tokyo, 13 (3): 85-102.

Kirkegand, J.P. 1959. The Polychaeta of West Africa. Part I: Sedentary species. Atl. Rep., Copenhagen, 5: 1-117.

Koлima, S. 1998. Paraphyletic status of Polychaeta suggested by phylogenetic analysis based on the amino acid sequences of elongation factor-1 $\alpha$. Mol. Phylogenet. Evol., Orlando, 9: 255-261.

Maddison, W.P. \& D.R. Maddison. 1992. MacClade: Analysis of Phylogeny and Character Evolution, version 3.05. [Computer software]. Sunderland, Sinauer Associates Inc.

Malmgren, A.J. 1867. Annulata Polychaeta Spetsbergiae, Groenlandiae, Islandiae et Scandinaviae hactenus cognita. Helsingforslæ, Ex Officina Frenckeliana, 127p.

McHugh, D. 1997. Molecular evidence that echiurans and pogonophorans are derived annelids. Proc. Natl. Acad. Sci., Washington, D.C., 94: 8006-8009.

Meyer, K. \& T. Bartolomaeus. 1996. Ultrastructure and formation of the hooked setae in Owenia fusiformis delle Chiaje, 1842: implications for annelid phylogeny. Can. Jour. Zool., Ottawa, 74 (12): 2143-2153.

Nilsen, R. \& T. Holthe. 1985. Arctic and Scandinavian Oweniidae (Polychaeta) with a description of Myriochele fragilis sp. n., and comments on the phylogeny of the family. Sarsia, Bergen, 70: 17-31.

Orrhage, L. 1964. Anatomische und morphologische Studien über die Polychaetenfamilien Spionidae, Disomidae und Poecilochaetidae. Zool. Bidr. Upps., Uppsala, 36: 335-405.

1978. On the structure and evolution of the anterior end of the Sabellariidae (Polychaeta Sedentaria), with some remarks on the general organisation of the polychaete brain. Zool. Jahrb. Abt. Anat. Ontog. Tiere, Jena, 100: 343-374.

- 1980. On the structure and homologues of the anterior end of the polychaete families Sabellidae and Serpulidae. Zoomorphology, Berlin, 96: 113-168.

PARAPAR, J. 2001. Revision of five species referred to Myriochele and Galathowenia (Polychaeta: Oweniidae) from the Antarctic seas based upon type material. Proc. Biol. Soc. Wash. 114 (2): 403-413.

PleiJel, F. 1991. Phylogeny and classification of the Phyllodocidae (Polychaeta). Zool. Scr., Oxon, 20 (3): $225-261$.

RousE, G. 1999. Trochophore concepts: ciliary bands and the evolution of larvae in spiralian Metazoa. Biol. J. Linn. Soc., London, 66: 411-464.

Rouse, G. \& K. Fauchald. 1997. Cladistics and polychaetes. Zool. Scr., Oxon, 26 (2): 139-204.

Schweigkofler, M.; T. Bartolomaeus \& L. V. Salvini-Plawen. 1998. Ultrastructure and formation of hooded hooks in Capitella capitata (Fabricius, 1780) (Capitellida, Annelida). Zoomorphology, Berlin, 118: 117-128.

Swofford, D.L. 1993. PAUP* - Phylogenetic Analysis Using Parsimony (*and Other Methods). Version 3.1.1. [Computer software and manual]. Sunderland, Massachusetts, Sinauer Associates Inc.

Watrous, L.E. \& Q.D. WheELER. 1981. The outgroup comparison method of character analysis. Syst. Zool., Washington, D.C., 30 (1): 1-11.

Westheide, W. 1997. The direction of evolution within the Polychaeta. Jour. Nat. Hist., London, 31: $1-15$.

Westheide, W.; D. McHugh; G. Purschke \& G. Rouse. 1999. Systematization of the Annelida: 
different approaches. In: A.W.C. DORRESTEIJN \& W. WESTHEIDE (Eds). Reproductive strategies and developmental patterns in annelids. Hydrobiologia, Dordrecht, 402: 291-307.

WILEY, E.O. 1981. Phylogenetics: The theory and practice of phylogenetic systematics. New York, John Wiley and Sons, 456p.

Wilson, D.P. 1932. On the mitraria larva of Owenia fusiformis Delle Chiaje. Philos. Trans. R. Soc. Lond. B Biol. Sci. 221: 231-334.

Received in 11.III.2001; accepted in 30.IX.2002. 